\title{
Physico-Chemical and Microbial Quality of Locally Composted and Imported Green Waste Composts in Oman
}

\author{
Saifeldin A. F. El-Nagerabi ${ }^{*}$, Abdulkadir E. Elshafie ${ }^{2}$, Saif N. Al-Bahry ${ }^{2}$, Hasina S. AlRawahi ${ }^{2}$, \\ Huda AlBurashdi ${ }^{2}$ \\ ${ }^{1}$ Department of Biological Sciences and Chemistry, College of Arts and Sciences, University of Nizwa, Birkat Al Mouz, Nizwa, \\ Sultanate of Oman; ${ }^{2}$ Department of Biology, College of Science, Sultan Qaboos University, AlKhoudh, Sultanate of Oman. \\ Email: nagerabi@unizwa.edu.om
}

Received August $7^{\text {th }}$, 2011; revised September 20 $0^{\text {th }}, 2011$; accepted October $20^{\text {th }}, 2011$.

\begin{abstract}
In this work the physical, chemical and microbial properties of four locally composted green waste composts (GWCs) namely Almukhasib, Growers, Plantex, and Super along with four imported GWC (Florabella, Mikskaar, Potgrond, and Shamrock) were studied to evaluate the quality of these composts with the acceptable standards. All composts showed normal physical properties, except the bad smell from sulfur reducing bacteria in Almukhasib, light brown color Plantex and one viable weed seed in Shamrock compost. The germination indexes of the composts comparable to the standard (90\%) were 100\% for Mikskaar, followed by Shamrock (92\%), Florabella (97), Potgrond (95\%), Plantex (98\%), Growers (77\%), and 5\% for both Super and Almukhasib. The physical and chemical properties vary considerably as follows: $\mathrm{pH} 3$ - 10.5, 5.1 - 6.5 (standard 5 - 8), electrical conductivity (EC) $0.4-10.2 \mathrm{mS} \cdot \mathrm{cm}^{-1}, 0.8-1.8 \mathrm{mS} \cdot \mathrm{cm}^{-1}$ (standard $0.0-4.0 \mathrm{mS} \cdot \mathrm{cm}^{-1}$ ), moisture content (MC\%) 29\% - 43.7\%, 64\% - 74\% (standard 35\% - 60\%) and water holding capacity (WHC\%) 92\% - 200\% and 400\% - 800\% for the locally produced and imported composts, respectively. Wide ranges in the chemical properties were expressed as ammonia concentration 512.4 - $1640.1 \mathrm{mg}^{\mathrm{kg}}{ }^{-1}, 459.4$ $656.5 \mathrm{mg} \cdot \mathrm{kg}^{-1}$ (standard $<500 \mathrm{mg} \cdot \mathrm{kg}^{-1}$ ), organic matter 17\% - 67.6\%, and 53.3\% - 66.2\% (standard 35\%) for the locally composted and imported composts, respectively. The concentrations of the heavy metals ( $\mathrm{Zn}, \mathrm{Ni}, \mathrm{Pb}, \mathrm{Hg}, \mathrm{As}, \mathrm{Cd}$, and $\mathrm{Cr}$ ) were lower than the recommended levels. The average of the bacterial colony forming unit per gram of locally produced and imported composts ranged between 260 - $1740 \mathrm{CFU} / \mathrm{g}$ and 330 - $2870 \mathrm{CFU} / \mathrm{g}$, whereas the fungal CFU were 10 - $2800 \mathrm{CFU/g}$ and 27 - $1800 \mathrm{CFU/g}$, respectively. The most probable number (MPN) for coliform bacteria was 43 $1100 \mathrm{CFU} / \mathrm{g}$ for locally produced composts, and 23 - $480 \mathrm{CFU} / \mathrm{g}$ for the imported composts. Therefore, these composts can not be used directly without effective treatment as substrate for plant growth, soil amendment and as biofertilizer.
\end{abstract}

Keywords: Aspergillus Niger, Coliform Bacteria, Physico-Chemical Properties, Green Waste Compost, Heavy Metals, Oman

\section{Introduction}

Composting is a natural decaying of the organic matter to stable compost by aerobic and anaerobic actions of bacteria, fungi and other organisms [1-3]. This process has the potential of managing organic materials in the waste stream such as leaves, farm wastes, animal manure, paper products, sewage sludge and domestic wastes $[1,4]$. Green waste compost (GWC) is a biodegradable waste that originates from pure plant materials of garden trimmings or garbage collected from vegetable and fruits markets [5]. It provides benefits for soil biological acti- vity, and nutritive value to plant growth [6-8]. It improves the physical and chemical properties of the soil [9], enhances plant growth $[10,11]$, remediates contaminated soil $[7,12-14]$, and suppresses some of these soil borne disease $[15,16]$.

Quality control of the compost significantly promotes the recycling of the organic wastes [17]. The compost must comply with certain national and international standards and quality grading $[5,18]$. The qualities of the compost include physical, chemical and biological properties such as moisture content, odor, carbon and nitrogen contents, phytotoxic substances, harmful elements, 
weeds, nutrient contents, plant pathogens and effectiveness to plant growth and soil amendment [19]. These can be maintained by the maturation of the compost and varied with the degree of transformation achieved by the organic materials [17]. Nonetheless, there is no single method that can be adopted universally to all compost types due to the wide range of feedstock, composting processes [20-22], and widely different chemical characteristics of organic wastes $[23,24]$. On the other hand, pathogens are commonly present in sewage and household wastes, both of which are commonly composted [25]. Therefore, composting is an efficient method for destruction of pathogens to safe and acceptable level for human, animal and plant uses [21,26].

In Oman, land is the major non-renewable resource facing the challenging threat of soil degradation. Sustainable agriculture must be environmentally safe and must produce adequate amounts of quality foods with minimum purchased fertilizers and rely, as much as possible, on the renewable resources of the farm itself $[27,28]$. This is especially important in $90 \%$ of the farms that exist in the third world, where agricultural inputs are often not available or affordable [27]. Thus, compost is one of the important low cost inputs for meeting nutrient requirements of crops [29]. In Oman, green waste composts are imported from other countries at high cost and economic burden, therefore, compost industry was locally developed for production of high quality composts with affordable prices to the small village farmers. The present study was conducted to evaluate the physical, chemical and microbial properties of locally produced and imported green waste composts in order to determine their ability to meet the acceptable standards.

\section{Materials and Methods}

\subsection{Compost Samples}

Four locally produced green waste composts (Almukhasib, Growers, Plantex, Super), and four imported composts (Florabella, Mikskaar, Potgrond, Shamrock) were selected. The samples were collected according to the Gulf standard number GS0901/1997 [5]. Five samples of $1 \mathrm{~kg}$ each were collected from the compost bags, mixed to form composite samples and were then divided into four working samples. The samples were kept $5^{\circ} \mathrm{C}$ for further analysis.

\subsection{Hydrophysical Characterization}

Immediately after collection, the samples were visually inspected for free flowing, hard lumps, objectionable odor, and color. The particle size of the composts was determined according to the Gulf standard number GS01167/2002 using three replicates of $100 \mathrm{~g}$ oven dried samples [18]. The samples were placed on $12 \mathrm{~mm}$ sieves and shaken for $5 \mathrm{~min}$ at 100 shakes per min [30]. The percentage of the particles greater than $12 \mathrm{~mm}$ was calculated as percentage by mass of the remaining materials on the top of the sieve to the mass of the test sample [31].

For testing the phytotoxicity of the compost samples and the presence of the viable seeds and plant parts, six plastic pots $(10 \times 15 \mathrm{~cm})$ were filled with the compost samples. Three pots were seeded with 100 seeds of Phaseolus mungo (mungbean) and the remaining three pots were kept without seeds. As a control, another 100 seeds of $P$. mungo were inoculated into plastic trays with moistened cotton and incubated in the green house of the Biology Department, Sultan Qaboos University and were moistened daily for 17 days. The pots were examined regularly for seed germination.

The hydrogen ion concentration $(\mathrm{pH})$, moisture contents (MC\%), electrical conductivity (EC), and water holding capacity (WHC \%) of the composts were measured using basic standard procedures and techniques [32]. The $\mathrm{pH}$ was determined in triplicate with the $\mathrm{pH}$ meter. For calculation of the moisture content, immediately after the collection of the samples, moisture content was determined by the oven method [33]. Replicates of $10 \mathrm{~g}$ were placed in glass Petri dishes; soft lumps were crushed with a spatula and dried at $105^{\circ} \mathrm{C}$ in an electric oven for 16 hours. The moisture content was determined as a percentage to the initial weight.

For detection of electrical conductivity (EC) of the composts samples, replicates of $2 \mathrm{~g}$ from each sample were mixed in $5 \mathrm{ml}$ of distilled water and the mixture was filtered through filtration unit with regular Whatman filter paper No. 42 (Whatman International Ltd, Maidstone, UK). The electrical conductivity of each filtrate was measured by electrical conductivity meter.

For determination of the water holding capacity (WHC\%) of the composts, $500 \mathrm{~g}$ from each sample were added to pre-weighed dry sieve and pressed evenly. The samples were saturated with water, kept covered over-night, and then the dripped water was wiped off the sieve with fine tissues. The sieve with the moistened sample was weighed, placed in desiccators, allowed to dry and then reweighed to calculate the amount of water held by the samples. The WHC was calculated as percentage mass of the absorbed water to the mass of the dried sample according to the gulf standard No. GS01/2002 [18].

\subsection{Chemical Analysis}

The organic matter (OM) of dried ground samples was determined by measuring the loss of mass through ignition at $550^{\circ} \mathrm{C}$ according to the modified combustion method suggested by many authors $[21,34,35]$ and adopted by the Gulf standard NO. GSO1167/2002 [18]. From each sample, $10 \mathrm{~g}$ were used instead of $5 \mathrm{~g}$ in order to in- 
crease the degree of the method accuracy. The samples were dried to constant mass in an oven at $105^{\circ} \mathrm{C}$ and cooled in desiccators to avoid moisture absorption from the atmosphere. Ten grams from each sample were put into an oven-dried porcelain dish, placed in the furnace and the temperature was increased to $550^{\circ} \mathrm{C}$ to convert the sample into ash. The percentage of the organic matter was calculated in triplicates as percentage loss of mass to the mass of the original test sample as a result of ignition.

The ammonia-nitrogen contents of the compost samples were determined in triplicate using Kjeldahl method (Kjeltec Foss, Tecator AB, Hogana, Sweden, N-analyzer). For this, $0.5 \mathrm{~g}$ from each sample and one keltab catalyst $\left(\mathrm{SeK}_{2} \mathrm{SO}_{4}\right)$ were added to a digestion tube and mixed with $10 \mathrm{ml}$ of sulfuric acid. The tubes were digested for 3 hours, allowed to cool and the concentration of the ammonia was measured.

For the heavy metal concentrations in the compost samples, $5 \mathrm{~g}$ from each sample were mixed with $25 \mathrm{ml}$ of distilled water and the mixture was filtered with Millipore filter papers. Ten $\mathrm{ml}$ from the filtrate were analyzed with Inductive Couple Plasma (ICP-MS OPTIMA, 3100 RL Spectrometer, Perkin Elmer and Norwalk, USA).

\subsection{Enumeration of Microorganisms}

The microorganisms including both fungi and bacteria were isolated from the compost using agar plate method. One gram from each sample was added to a test tube containing $9 \mathrm{ml}$ sterile distilled water, vortexed, and serial dilutions were prepared. One ml was aseptically inoculated on Potato Dextrose Agar (PDA) for fungal growth, and similarly Nutrient Agar (NA) was inoculated for bacterial growth. The inoculated PDA plates were incubated at $28^{\circ} \mathrm{C}$ for 7 days, and the NA plates were incubated at $37^{\circ} \mathrm{C}$ for 48 hours. At the end of the incubation period, the number of colony forming units (CFU) per gram of the compost was calculated. The isolated fungi were identified using different taxonomic books and monographs. The presence of coliform bacteria in the compost samples was screened using the standard table of the most probable number (MPN).

\subsection{Statistical Analysis}

Duncan's multiple range and one way ANOVA were used for comparison between the compost types with $p=$ 0.05 . The analysis was carried out using statistical package software SPSS (version 11.0).

\section{Results and Discussion}

\subsection{Physical Properties}

Four locally produced green waste composts (Almukhasib, Growers, Plantex, and Super), and four imported composts (Florabella, Mikskaar, Potgrond, and Sham- rock) were examined for their physical, chemical and microbial properties. The visual inspection showed that all the samples were physically uniform, free flowing, no hard lumps, dark brown to black in color, free from objectionable odor, absent of foreign seeds and particle size less than $12 \mathrm{~mm}$, except the bad smell of Almukhasib, light brown color of Plantex, and one viable weed seed in shamrock (Table 1). These characteristics indicate the good quality of the composts, the completion of the degradation process and compost maturity as suggested by many authors $[23,36]$. The bad smell of the composts is due to production of hydrogen sulfide by sulfur reducing bacteria or faecal coliforms present in animal dropping mixed with plant materials without any pretreatment [23]. These odorous fumes contained hydrogen sulfide, methylmercaptan, and methylsulfide, and were present in large quantities at the initial stage of composting which decreased rapidly with maturation [19]. The presence of viable weed seeds and brown color of the composts was associated with compost immaturity [36].

Seed germination indexes in compost or compost extracts are common biological methods to evaluate the degree of the maturity of the composted materials (the decomposition of phototoxic substance) and acids produced during the early active composting stages [24,37]. In the present study, the germination percentages of the mungbean seeds in the tested composts were reported (Table 1). The germination percentages (in parenthesis) of the mungbean seeds in each of the corresponding compost were as follows: Mikskaar (100\%), Shamrock (92\%), Florabella (97\%), Potgrond (95\%), Plantex (98\%), Growers (77\%), and 5\% for Super and Almukhasib. The germination levels in locally produced Super (5\%), Almukhasib (5\%) and Growers (77\%) which were lower than the acceptable index (>90\%) can be attributed to the phytotoxic effects of the organic acid and ammonia toxicity produced during the active composting process [37, 38]. Therefore, these composts were not suitable for many potential uses. In the present study, the ammonia concentration of the imported composts were: Mikskaar $\left(617.9 \mathrm{mg} \cdot \mathrm{kg}^{-1}\right)$, Shamrock $\left(656.5 \mathrm{mg} \cdot \mathrm{kg}^{-1}\right)$, Florabella $\left(570.5 \mathrm{mg} \cdot \mathrm{kg}^{-1}\right)$, Potgrond $\left(459.4 \mathrm{mg} \cdot \mathrm{kg}^{-1}\right)$, whereas the locally produced composts showed relatively higher ammonia concentration for Super $\left(1640.1 \mathrm{mg} \cdot \mathrm{kg}^{-1}\right)$, Growers (1156.4 mg.kg-1 ), Almukhasib (804.2 mg. $\mathrm{kg}^{-1}$ ), and Plantex (712.4 mg. $\mathrm{kg}^{-1}$ ) (Table 2). Similarly, the electrical conductively (EC) which indicates the salt contents of the compost is injurious to plant roots and prevents their growth [39]. Therefore, the low level of germination of the bean seeds in locally produced composts may be associated with the high electric conductivity of Super $\left(10.2 \mathrm{mS} \cdot \mathrm{cm}^{-1}\right)$, Almukhasib $\left(5.4 \mathrm{mS} \cdot \mathrm{cm}^{-1}\right)$ and Growers $\left(7.5 \mathrm{mS} \cdot \mathrm{cm}^{-1}\right)$ which were higher than the upper standard limit $\left(4 \mathrm{mS} \cdot \mathrm{cm}^{-1}\right)$ (Table 3). The imported Mik- 
Table 1. Physical properties of the locally produced and imported green waste composts.

\begin{tabular}{|c|c|c|c|c|c|c|c|c|}
\hline \multirow{2}{*}{ Properties } & \multicolumn{4}{|c|}{ Locally produced composts } & \multicolumn{4}{|c|}{ Imported composts } \\
\hline & Almukhasib & Growers & Plantex & Super & Florabella & Mikskaar & Potgrond & Shamrock \\
\hline Free flowing & + & + & + & + & + & + & + & + \\
\hline Hard lumps & - & - & - & - & - & - & - & - \\
\hline Objectionable odor & + & - & - & - & - & - & - & - \\
\hline Normal color & + & + & $-*$ & + & + & + & + & + \\
\hline Particle size $<12 \mathrm{~mm}$ ) & + & + & + & + & + & + & + & + \\
\hline Foreign seeds & - & - & - & - & - & - & - & $+* *$ \\
\hline Germination \% & 5 & 77 & 98 & 5 & 98 & 100 & 95 & $<90 \%$ \\
\hline
\end{tabular}

*Light brown color compost; **presence of only one germinated weed seed.

Table 3. Hydrophysical properties of the locally produced and imported green waste composts.

\begin{tabular}{|c|c|c|c|c|c|c|c|c|c|}
\hline \multirow{2}{*}{ Properties } & \multicolumn{4}{|c|}{ Locally produced composts } & \multicolumn{4}{|c|}{ Imported composts } & \multirow{2}{*}{ Standards } \\
\hline & Almukhasib & Growers & Plantex & Super & Florabella & Mikskaar & Potgrond & Shamrock & \\
\hline $\mathrm{pH}$ & $10.1 \mathrm{a}^{\mathrm{a}}$ & $7.8 \mathrm{~b}$ & $3.0 \mathrm{e}$ & $8.1 \mathrm{~b}$ & $5.2 \mathrm{~d}$ & $6.4 \mathrm{c}$ & $5.6 \mathrm{~d}$ & $5.1 \mathrm{~d}$ & $5-8$ \\
\hline Electrical conductivity $\left(\mathrm{mS} \cdot \mathrm{cm}^{-1}\right)$ & $5.4 \mathrm{c}$ & $7.9 \mathrm{~b}$ & $0.4 \mathrm{e}$ & $10.2 \mathrm{a}$ & $1.2 \mathrm{~d}$ & $0.4 \mathrm{e}$ & $0.8 \mathrm{e}$ & $1.8 \mathrm{~d}$ & $0-4$ \\
\hline Moisture content (\%) & $29 \mathrm{f}$ & $35 \mathrm{e}$ & $43.7 \mathrm{~d}$ & 33 e & 65 c & $74 \mathrm{a}$ & $70.5 \mathrm{~b}$ & $64 \mathrm{c}$ & $35-60$ \\
\hline Water holding capacity (\%) & $92 \mathrm{~g}$ & 200 e & 200 e & $144 \mathrm{f}$ & $400 \mathrm{~d}$ & 646 c & $800 \mathrm{a}$ & $57 \mathrm{~b}$ & \\
\hline
\end{tabular}

${ }^{a}$ Within rows, number with different lower case letters differ significantly $(\mathrm{P}<0.05)$.

Table 2. Chemical properties and heavy metals concentration (ppm) in the locally produced and imported green waste composts.

\begin{tabular}{|c|c|c|c|c|c|c|c|c|c|}
\hline \multirow{2}{*}{ Properties } & \multicolumn{4}{|c|}{ Locally produced composts } & \multicolumn{4}{|c|}{ Imported composts } & \multirow{2}{*}{ Standards } \\
\hline & Almukhasib & Growers & Plantex & Super & Florabella & Mikskaar & Potgrond & Shamrock & \\
\hline Ammonia (mg/kg) & $804.2 \mathrm{c}^{\mathrm{b}}$ & $1156.4 \mathrm{~b}$ & $712.4 \mathrm{~d}$ & $1640.1 \mathrm{a}$ & $570.5 \mathrm{~g}$ & $617.9 f$ & $459.4 \mathrm{~h}$ & $656.5 \mathrm{e}$ & $<500$ \\
\hline Organic matter \% & $17 \mathrm{~g}$ & $22 \mathrm{f}$ & 67.6 a & 25 e & $53.3 \mathrm{~d}$ & $64 \mathrm{c}$ & $66.2 \mathrm{~b}$ & 65 bc & 35 \\
\hline Copper (Cu) & $0.05 \mathrm{bc}$ & $0.11 \mathrm{a}$ & $0.03 \mathrm{c}$ & $0.04 \mathrm{c}$ & 0.05 bc & $0.08 \mathrm{~b}$ & $0.12 \mathrm{a}$ & $0.06 \mathrm{bc}$ & $150-250$ \\
\hline Nickel (Ni) & 0.03 a & $0.03 \mathrm{a}$ & $0.04 \mathrm{a}$ & $0.04 \mathrm{a}$ & $0.02 \mathrm{a}$ & 0.03 a & $0.03 \mathrm{a}$ & 0.03 a & $50-70$ \\
\hline Lead (Pb) & $0.02 \mathrm{a}$ & $0.02 \mathrm{a}$ & $0.03 \mathrm{a}$ & $0.03 \mathrm{a}$ & $0.01 \mathrm{a}$ & $0.03 \mathrm{a}$ & $0.03 \mathrm{a}$ & $0.02 \mathrm{a}$ & $120-150$ \\
\hline Cadmium (Cd) & $0.08 \mathrm{a}$ & $0.04 \mathrm{~b}$ & $0.03 \mathrm{~b}$ & $0.08 \mathrm{a}$ & $0.08 \mathrm{a}$ & $0.03 \mathrm{~b}$ & $0.03 \mathrm{~b}$ & $0.02 \mathrm{~b}$ & $3-5$ \\
\hline Arsenic (As) & $0.04 \mathrm{a}$ & $0.04 \mathrm{a}$ & 0.05 a & $0.05 \mathrm{a}$ & $0.04 \mathrm{a}$ & 0.03 a & $0.05 \mathrm{a}$ & $0.04 \mathrm{a}$ & $15-25$ \\
\hline Chromium (Cr) & $0.34 \mathrm{e}$ & $0.54 \mathrm{~b}$ & $0.29 \mathrm{f}$ & $0.39 \mathrm{~d}$ & $0.45 \mathrm{c}$ & $0.50 \mathrm{~b}$ & $0.19 \mathrm{~g}$ & $0.57 \mathrm{a}$ & $100-150$ \\
\hline Zinc (Zn) & $114.4 \mathrm{~b}$ & $60 \mathrm{e}$ & $100 \mathrm{c}$ & $18.8 \mathrm{~g}$ & $30.0 \mathrm{f}$ & $79.4 \mathrm{~d}$ & $120 \mathrm{a}$ & $120.7 \mathrm{a}$ & $350-500$ \\
\hline Mercury (Hg) & $0.0059 \mathrm{a}$ & $0.0059 \mathrm{a}$ & 0.0059 a & 0.0059 a & 0.0059 a & 0.0059 a & $0.0059 \mathrm{a}$ & $0.0059 \mathrm{a}$ & $1.5-3$ \\
\hline
\end{tabular}

${ }^{\mathrm{b}}$ Within rows, number with different lower case letters differ significantly $(P<0.05)$.

skaar $\left(0.4 \mathrm{mS} \cdot \mathrm{cm}^{-1}\right)$, Shamrock $\left(1.8 \mathrm{mS} \cdot \mathrm{cm}^{-1}\right)$, Potgrond $\left(0.8 \mathrm{mS} \cdot \mathrm{cm}^{-1}\right)$, Florabella $\left(1.2 \mathrm{mS} \cdot \mathrm{cm}^{-1}\right)$, Potgrond $(0.8$ $\left.\mathrm{mS} \cdot \mathrm{cm}^{-1}\right)$, Florabella $\left(1.2 \mathrm{mS} \cdot \mathrm{cm}^{-1}\right)$, and the locally produced Plantex compost $\left(0.4 \mathrm{mS} \cdot \mathrm{cm}^{-1}\right)$ displayed higher levels of germination and their electrical conductivity was within the standard limit $\left(0-4 \mathrm{mS} \cdot \mathrm{cm}^{-1}\right)$ which is not harmful to the plant growth. In a similar study, it was found that the electrical conductivity varies considerably and ranged between 0.12 and $17.08 \mathrm{mS} \cdot \mathrm{cm}^{-1}$ [40]. This wide range of electrical conductivity expressed the diversity of the chemical and microbial properties of the various compost products.

\subsection{Hydrophysical Properties of the Compost}

The hydrogen ion concentrations $(\mathrm{pH})$ for the compost varied at the beginning of composting process and ramped 
from 7.3 to 7.7 as the composting proceeded up to 8.8 9.6 [2]. All the screened composts, except the locally processed Almukhasib, showed acceptable $\mathrm{pH}$ value (5 8.0) (Table 3). However, the highly acidic Plantex ( $\mathrm{pH} 3)$ may be due to production of phytotoxic organic acids during immature composting process which causes immediate growth injuries [38]. Therefore, the addition of this compost to soil may modify the $\mathrm{pH}$ of the final mix and buffer the soil $\mathrm{pH}$ [1].

The moisture contents of the composts ranged between $3.1 \%-82.7 \%$ and varied considerably with the variation in the composted materials [40]. The moisture content values for the compost was considerably high in the first 3 weeks of composting after which it increased significantly in the later weeks [1]. Therefore, the addition of compost provides excellent drought resistance and great efficient water retention. In the present research (Table $3)$, the moisture contacts of the imported Shamrock is $64 \%$, followed by Florabella (65\%), Potgrond (70.5\%) and Mikskaar (74\%), which were higher than the acceptable limits (35\% - 60\%), comparable to and locally produced Plantex (43\%), Growers (35\%), Super (33\%), and Almukhasib (29\%). The moisture content ranged between $50 \%-60 \%$ and was considered as the optimal level for further composting [41]. Therefore, the compost with higher moisture content will inhibit aerobic degradation and enhance the unpleasant odor from the growth of anaerobic sulfate reducing bacteria. Yet, the ideal moisture content depends on how one plans to use the compost.

Water retention capacity of substrate is generally considered as the quality determining factor [30,42]. The highest saturation of the compost is $75 \%$ and the good compost must have high water holding capacity and low filtration rate for supporting the plant growth. In the present study (Table 3), the water holding capacity (WHC\%) of the tested composts was found to be more than their actual weight. The water holding capacity of the imported composts ranged between $400 \%$ and $800 \%$ (Florabella $400 \%$, Mikskaar 646\%, shamrock 757\%, Potgrond 800\%) which is significantly higher than the locally processed Almukhasib (92\%), Super (144\%), Growers and Plantex compost (200\%). Therefore, these composts can be used separately or mixed with sandy soil of low water holding capacity if they satisfy the other quality control parameters and the essential requirements for the plant growth.

\subsection{Chemical Properties of the Compost}

Wide range in the values of the chemical properties of the compost expressed the diversity of various compost products and the raw materials used [40]. The total carbon contents (TC) for various composts were in the range of between $16.9 \%-51.0 \%$. A approximately $11 \%-27 \%$ of the total carton was lost during the 7 days of active composting, and $62 \%$ - $66 \%$ during the whole composting time [43]. In the present results (Table 2), the total organic matter for the imported Potgrond (66.2\%), Shamrock (65\%), Mikskaar (64\%), Florabella (53.5\%), and locally produced Plantex (67.6\%), were relatively higher than the standard set by the Gulf countries (35\% and optimum $40 \%-60 \%$ ) [5]. On the other hand, the organic contents of the locally produced Super (25\%), Growers (22\%), and Almukhasib (17\%) were below the standard limit. The high organic matter contents of the compost indicate the presence of uncomposted organic materials that can be degraded slowly by microorganisms and eventually used by higher plants [44].

Heavy metals, as harmful elements, are one of the determinant factors for compost quality [19]. They may come from sewage water, addition of manure from chicken and other animal dung, and from soil added to the composted materials. They are released from compost and negatively affect the plant during the slow degradation process. On the contrary, compost reduces the mobility of some toxic metals to the plants through formation of some complexes. In this study, although there are significant variations in the heavy metals concentrations (Zn, Ni, Pb, Hg, As, Cd, Cr) between the screened composts, the concentration levels of heavy metals in the compost samples were lower than the acceptable limits recommended by the Gulf countries [5]. Similar standard limits were adopted in Germany [45], and Canada [46]. Nonetheless, the high contents of heavy metals may be due to addition of these metals to animal feeds [19] or contamination during the composting process [47].

\subsection{Microbial Estimates of the Compost}

It is natural to have large numbers of bacteria and fungi in the compost during composting process and they are essential for slow degradation of partially decomposed organic materials [1]. The pathogenic fungi and bacteria were normally detected in composted household wastes, and sewage sludge [25]. Nonetheless, composting is an efficient method for destruction of pathogenic microorganisms in the compost to a safer level for humans, animals and plants $[21,26]$. Reasonable amounts of microorganisms are still present in the compost at maturity [1]. In the present study, the average of the bacterial colony forming unit per gram of the compost were as follows: Plantex (260 cfu/g), Almukhasib (280 cfu/g), Shamrock (330 cfu/g), Growers (1490 cfu/g), Potgrond (1720 cfu/g), Super (1740 cfu/g), Mikskaar (2580 cfu/g), and Florabella compost (2870 cfu/g), whereas the colony forming unit of fungi in the compost were Almukhasib (10 cfu/g), Shamrock (30 cfu/g), Super (190 cfu/g), Florabella (200 cfu/g), Mikskaar (270 cfu/g), Plantex (360 cfu/g), Pot- 
grond (1800 cfu/g), and Growers (2800 cfu/g) (Table 4). It is evident that the imported Florabella, Mikskaar, and the locally produced Super composts have the highest bacterial colonies, whereas the imported Potgrond, and the locally produced Growers and Plantex contain relatively high numbers of fungal colonies. These large numbers of bacterial and fungal colonies were responsible for the slow degradation of the organic matter as suggested by several authors $[21,23,48]$. Most of the fungi involved in the slow degradation of the screened composts belong to the thermophilic genus and moisture tolerant Aspergillus. In the present study (Table 4), A. niger was the predominant species recovered from all compost types $(100 \%)$ at the later stage as reported by many authors [1, 48,49]. This fungus was followed by A. fumigatus (75\%), A. sparsus (50\%), yeasts (50\%), A. flavus (37.5\%), where the remaining fungi such as $A$. restrictus, $A$. versicolor, Cladosporium spp., and Penicillium spp. were recovered from $50 \%$ of the compost types, and to a lesser extent Acremonium sp. and A. ochraceous (12.5\%). In similar studies, different species of Aspergillus and Penicllium were isolated from the compost $[1,8,48]$.

Various pathogenic bacteria were isolated from different composts and composted materials [1,21]. The major faecal coliforms found in the raw materials composed of Escherichia coli, where in the finished compost the majority of the faecal coliforms were probably of nonfaecal origin [21]. Therefore, the species composition of the faecal coliforms can vary considerably depending on the composted materials and composting system. In the present results, the most probable number (MPN) was used to determine the faecal contamination of the composts. Our findings (Table 4) showed that locally produced Almukhasib was highly contaminated with coliforms (1100 cfu/g), followed by the imported Florabella (480 cfu/g), Potgrond (240 cfu/g), and to a lesser extent by locally produced Plantex (150 cfu/g), Growers (93 cfu/g), Super (43 cfu/g), and the imported Mikskaar (43 $\mathrm{cfu} / \mathrm{g}$ ) and Shamrock (23 cfu/g). The presence of higher number of coliforms in the locally processed Almukhasib, followed by imported Florabella and Potgrond indicates the possible contamination of these composts with sewage water or other animal products during composting process, which was confirmed by isolation of coliform bacteria as suggested by many researchers $[1,21]$. Therefore, there is a high possibility of transmission of serious diseases during handling and usage of these composts in addition of expected infestation of the cultivated plants with serious pathogenic bacteria.

\section{Conclusions}

It is apparent that all the investigated composts were free from most of the physical constraints, except the light brown color of Plantex, bad smell of Almukhasib and viable seed in Shamrock which indicates immaturity of the composts. The locally processed composts contain phytotoxic acids, ammonia, and with high electrical conductivity which affect the seed germination. The moisture contents of the imported Florabella, Mikskaar, Potgrond, and Shamrock were higher than the locally pro-

Table 4. Microbial properties of the locally produced and imported green waste composts.

\begin{tabular}{|c|c|c|c|c|c|c|c|c|}
\hline \multirow{2}{*}{ Properties } & \multicolumn{4}{|c|}{ Locally produced composts } & \multicolumn{4}{|c|}{ Imported composts } \\
\hline & Almukhasib & Growers & Plantex & Super & Florabella & Mikskaar & Potgrond & Shamrock \\
\hline Bacteria (CFU/g) & $280 \mathrm{~h}^{*_{\mathrm{c}}}$ & $1490 \mathrm{e}$ & $260 \mathrm{~g}$ & $1740 \mathrm{c}$ & 2870 a & $2580 \mathrm{~b}$ & $1720 \mathrm{~d}$ & $330 \mathrm{f}$ \\
\hline Fungi (CFU/g) & $10 \mathrm{~h}$ & $2800 \mathrm{a}$ & $360 \mathrm{c}$ & $190 \mathrm{f}$ & $200 \mathrm{e}$ & $270 \mathrm{~d}$ & $1800 \mathrm{~b}$ & $30 \mathrm{~g}$ \\
\hline MPN (CFU/g) & $1100 \mathrm{a}$ & $93 \mathrm{e}$ & $150 \mathrm{~d}$ & $43 \mathrm{f}$ & $480 \mathrm{~b}$ & $43 \mathrm{f}$ & $240 \mathrm{c}$ & $23 \mathrm{~g}$ \\
\hline Acremonium sp. & - & - & - & - & - & - & + & - \\
\hline Aspergillus flavus & - & - & + & + & - & - & - & + \\
\hline A. fumigatus & - & + & + & + & - & + & + & + \\
\hline A. niger & + & + & + & + & + & + & + & + \\
\hline A. ochraceous & - & - & + & - & - & - & - & - \\
\hline A. sparsus & + & - & - & + & - & + & - & + \\
\hline A. restrictus & - & - & - & + & - & + & - & - \\
\hline A. versicolor & - & - & - & - & + & - & - & + \\
\hline Cladosporium sp. & - & + & - & - & - & - & + & - \\
\hline Penicillium sp. & - & - & - & + & + & - & - & - \\
\hline Yeasts & + & + & - & - & - & - & + & + \\
\hline
\end{tabular}

${ }^{\mathrm{c}}$ Within rows, number with different lower case letters differ significantly $(P<0.05)$. 
duced Almukhasib, Growers, Plantex, and Super composts. The water holding capacity was significantly higher in all composts and meets the standard limit. The total organic matters were higher in the imported composts in comparison with the locally composted materials. The heavy metals contents of all composts were below the acceptable limits. The composts were contaminated with variable levels of saprophytic fungi and coliform bacteria. It is evident the imported composts were relatively better than the locally produced composts, however, none of them meet most of the recommended characteristics [50]. Therefore, they can not be used directly and without any treatment as media for plant growth, soil biofertilizer and for soil amendment. Therefore, there is a high necessity for setting detailed legislation, regulation policies, proper testing methods, quality control measurements, and strong quarantine regulations for exportimport and local production of green waste composts. Attention should be given to the local production of high quality composts which serve the environment, waste management, recycling industry and satisfaction of the local markets.

\section{Acknowledgements}

We thank the Department of Biology, College of Science, Sultan Qaboos University for providing space and faculties to carry out this research. Dr. Tom Hughes of University of Nizwa Writing Center proof read the English of this manuscript. Dr. Peter Cowan of the Department of Biological Sciences and Chemistry, University of Nizwa, improved the scientific content of the article.

\section{REFERENCES}

[1] D. V. Adegunloye, F. C. Adetuyi, F. A. Akinyosoye and M. O. Doyeni, "Microbial Analysis of Compost Using Cow Dung as Booster," Pakistan Journal of Nutrition, Vol. 6, 2007, pp. 506-610. doi:10.3923/pjn.2007.506.510

[2] R. Briancesco, A. M. Coccia, G. Chairetti, S. Della, Libera, M. Semproni and L. Bonadonna, "Assessment of Microbiological and Parasitological Quality of Composted Wastes: Health Implications,” Waste Management and Research, Vol. 26, No. 2, 2008, pp. 196-202. doi:10.1177/0734242X07085064

[3] K. Salvator and W. E. Sabee, "Evaluation of Fertilizer Value and Nutrient Release from Corn and Soybean Residue under Laboratory and Greenhouse Conditions,” Communication in Soil Science and Plant Analysis, Vol. 26, No. 3-4, 1995, pp. 469-484. doi:10.1080/00103629509369312

[4] J. A. Adeniran, L. B. Taiwo and R. A. Sobulo, "Effects of Organic Wastes and Method of Composting on Compost Maturity, Nutrient Composition of Compost and Yield of Two Vegetable Crops,” Journal of Sustainable Agriculture, Vol. 22, No. 4, 2003, pp. 95-101. doi:10.1300/J064v22n04_08
[5] Anonymous, "Municipal Solid Waste Compost," Standardization Organization for G. C. C. (GSO) 901, 1997.

[6] R. Barberis and P. Nappi, "Evaluation of Compost Stability,” In: M. de Bertoldi, et al., Eds., The Science of composting, Blackie Academic and Professional, Glasgow, 1996, pp. 175-184.

[7] W. Hartley, N. M. Dickison, P. Riby and N. W. Lepp, "Arsenic Mobility in Brownfield Soils Amended with Green Waste Compost or Biochar and Planted with Miscanthus," Environmental Pollution, Vol. 157, No. 10, 2009, pp. 2654-2662. doi:10.1016/j.envpol.2009.05.011

[8] G. Straatsma, R. A. Samson, T. W. Olijnsma, H. J. M. O. P. Den Camp, J. P. G. Gerrits and L. J. L. D. van Griensven, "Ecology of Thermophilic Fungi in Mushroom Compost, with Emphasis on Scytalidium thermophilum and Growth Stimulation of Agaricus biosporus Mycelium," Applied and Environmental Microbiology, Vol. 60, 1994, pp. 454-458.

[9] R. C. Dalal, I. Gibson, D. E. Allen and N. W. Menzies, "Green Waste Compost Reduces Nitrous Oxide Emissions from Feedlot Manure Applied to Soil,” Agriculture, Ecosystems and Environment, Vol. 10, 2009, pp. 1-9.

[10] M. Ali, A. J. Griffith, K. P. Williams and D. L Jones, "Evaluating the Growth Characteristics of Lettuce in Vermicompost and Green Waste Compost,” European Journal of Soil Biology, Vol. 43, 2007, pp. 316-319. doi:10.1016/j.ejsobi.2007.08.045

[11] A. A. Keeling, K. R. McCallum and C. P. Beckwith, "Mature Green Waste Compost Enhances Growth and Nitrogen Uptake in Wheat (Triticum aestivum L.) and Oil Seed Rape (Brassica napus L.) through the Action of Water-Extractable Factors," Bioresource Technology, Vol. 90, No. 2, 2003, pp. 127-132. doi:10.1016/S0960-8524(03)00125-1

[12] P. Alvarenga, A. P. Goncalves, R. M. Fernandes, A. de Varennes, E. Duarte, A. C. Cunha-Queda and G. Vallin, "Reclamation of a Mine Contaminated Soil Using Biologically Reactive Organic Matrices,” Waste Management and Research, Vol. 27, No. 2, 2009, pp. 101-111. doi:10.1177/0734242X08091556

[13] R. Van Herwijnen, T. R. Hutchings, A. Al-Tabbaa, A. J. Moffat, M. L. Johns and S. K. Ouki, "Remediation of Metal Contaminated Soil with Mineral-Amended Composts,” Environmental Pollution, Vol. 150, No. 3, 2007, pp. 347-354. doi:10.1016/j.envpol.2007.01.023

[14] R. van Herwijnen, S. K. Ouki, A. Al-Tabbaa, A. J. Moffat, M. L. Johns and T. R. Hutchings, "The Effect of Two Different Composts on the Performance and Metal Uptake of Poplar Growing on Heavy Metal Contaminated Soil,” SEESOIL, Vol. 17, 2008, pp. 39-48.

[15] J. Lozano, W. J. Blok and A. J. Termorshuizen, "Effect of Compost Particle Size on Suppression of Plant Diseases," Environmental Engineering Science, Vol. 26, No. 3, 2009, pp. 601-607. doi:10.1089/ees.2008.0002

[16] D. J. Van deer Gaag, F. R. van Noort, L. H. M. StapelCuijpers, C. de Kreij, A. J. Termorshuizen, E. van Rijn, S Zmora-Nahum and Y. Chen, "The Use of Green Waste 
Compost in Peat-Based Potting Mixtures: Fertilization and Suppressiveness against Soil Borne Diseases," Scientia Horticulturae, Vol. 114, No. 4, 2007, pp. 289-297. doi:10.1016/j.scienta.2007.06.018

[17] M. T. C. Mondini,. L Dell’Abate, Leita and A. Benedetti, "An Integrated Chemical, Thermal, and Microbiological Approach to Compost Stability Evaluation,” Journal of Environmental Quality, Vol. 32, No. 6, 2003, pp. 23792386. doi:10.2134/jeq2003.2379

[18] Anonymous, "Test Method of Potting Mixes (Potting Soil)," Standardization Organization for G. C. C. (GSO) 1169, 2002.

[19] Y. Harada, K. Haga, T. Osada and M. Koshino, "Quality of Compost Produced from Animal Wastes,” JARQ, Vol. 26, No. 4, 1993, pp. 238-246.

[20] Y. Chen, Y. Inbar, B. Chefetz and Y. Hadar, "Compost and Recycling of Organic Wastes P.341-362,” In: D Rosen, et al., Eds., Modern Agriculture and Environment, Kulwer Academic Publishers, Dordrecht, 1996.

[21] K. K. Christensen, M. Carisbaek and E. Kron, "Strategies for Evaluating the Sanitary Quality of Composting," Journal of Applied Microbiology, Vol. 92, 2002, pp. 1143-1158. doi:10.1046/j.1365-2672.2002.01648.x

[22] M. Itävaara, O. Venelampi, M. Vikman and A. Kapanen, "Compost Maturity-Problem Associated with Testing," In: $\mathrm{H}$ Insam, et al., Eds., Microbiology of Composting, Springer Verlag, Heidelberg, 2002, pp. 373-382

[23] M. Benito, A. Masaguer, A. Moliner, N. Arrigo and R. M. Palma, "Chemical and Microbial Parameters for the Characterization of the Stability and Maturity of Pruning Waste Compost,” Biology of Fertile Soils, Vol. 37, No. 3, 2003, pp. 184-189.

[24] T. J. He, X. T. Logan and S. J. Traine, "Physical and Chemical Characteristics of Selected U.S. Municipal Waste Composts," Journal of Environmental Quality, Vol. 24, No. 3, 1995, pp. 543-552. doi:10.2134/jeq1995.00472425002400030022x

[25] H. Pahren, "Microorganisms in Municipal Solid Waste and Public Health Applications," CRC Critical Reviews in Environmental Control, Vol. 17, 1987, pp. 187-228. doi:10.1080/10643388709388334

[26] S. Dumontet, H. Dinel and S. B. Baloda, "Pathogen Reduction in Sewage Sludge by Composting and Other Biological Treatments. A review," Biological Agriculture and Horticulture, Vol. 16, No. 4, 1999, pp. 409-430.

[27] C. Chitravadivu, V. Balakrishnan, J. Manikandan, T. Elavazhagan and S. Jayakumar, "Application of Food Waste Compost on Soil Microbial Population in Groundnut Cultivated Soil, India," Middle-East Journal of Scientific Research, Vol. 4, No. 2, 2009, pp. 90-93.

[28] G. Sarwar, H. Schmeisky, N. Hussain, S. Muhammad, M. Ibrahim and E. Safdar, "Improvement of Soil Physical and Chemical Properties with Compost Application in Rice-Wheat Cropping System," Pakistan Journal of Botany, Vol. 40, No. 1, 2008, pp. 275-282.

[29] F. Zameer, S. Meghashri, S. Copal and B. R. Rao, "Chemical and Microbial Dynamics during Composting of Herbal Pharmaceutical Industrial Waste,” E-Journal of Chemistry, Vol. 7, No. 1, 2010, pp. 143-148.

[30] M. Abd El-Hady and E. I. El-Dirdiry, "Improving Hydrophysical Properties of Compost," Journal of Applied Sciences Research, Vol. 2, No. 12, 2006, pp. 1137-1141.

[31] R. Orozco, S. Gschwander and O. Marfa, "Substrate Classification from Particle Size Analysis," Acta Horticulturae, Vol. 450, 1997, pp. 397-403.

[32] G. C. S. Wilson, "The Physio-Chemical and Physical Properties of Horticultural Substrates," Acta Horticulturae, Vol. 150, 1983, pp. 19-32.

[33] S. A. F. El-Nagerabi and A. E Elshafie, "Incidence of See-Borne Fungi and Aflatoxins in Sudanese Lentil Seeds,” Mycopathologia, Vol. 149, 2000, pp. 151-156. doi:10.1023/A:1007241125586

[34] Y. Inbar, Y. Chen and Y. Hadar, "Humic Substances Formed during the Composting of Organic Matter," Soil Science Society of America Journal, Vol. 54, No. 5, 1990, pp. 1316-1323. doi:10.2136/sssaj1990.03615995005400050019x

[35] A. C. Petrus, O. H. Ahmed, A. N. Muhamed, H. M. Nassir, M. Jiwan and M. G Banta, "Chemical Characteristic of Compost and Humic Acid from Sago Waste (Metroxylon sagu) ," American Journal of Applied Sciences, Vol. 6, No. 11, 2009, pp. 1880-1884. doi:10.3844/ajassp.2009.1880.1884

[36] E. Iglesias-Jiménez and V. Pérez-Garcia, "Determination of Maturity Indices for City Refuses Composts,” Agriculture, Ecosystems and Environment, Vol. 38, No. 4, 1992, pp. 331-343. doi:10.1016/0167-8809(92)90154-4

[37] G. A. Wu, L. Ma and L. Q. Martinez, "Comparison of Methods for Evaluating Stability and Maturity of Biosolids Compost,” Journal of Environmental Quality, Vol. 29, No. 2, 2000, pp. 424-429. doi:10.2134/jeq2000.00472425002900020008x

[38] M. H. Wong, "Phytotoxicity of Refuse Compost during the Process of Maturation,” EA, Ecological and Biological, Vol. 37, 1985, pp. 159-174.

[39] H. Cai, T. Chen, H. Liu, D. Gao, G. Zheng and J. Zhang, "The Effect of Salinity and Porosity of Sewage Sludge Compost on the Growth of Vegetable Seedlings," Scientia Horticulturae, Vol. 124, No. 3, 2010, pp. 381-386. doi:10.1016/j.scienta.2010.01.009

[40] J. C. Tang, "Chemical and Microbial Properties of Various Compost Products,” Soil Science and Plant Nutrition, Vol. 49, 2003, pp. 273-280.

[41] S. M. Tiquia, N. F. Y T.am and I. J. Hodgkiss, "Microbial Activity during Composting of Spent Pig-Manure Sawdust Litter at Different Moisture Contents,” Bioresource Technology, Vol. 55, 1996, pp. 2010-206. doi:10.1016/0960-8524(95)00195-6

[42] J. Caron and V. K. N. Nkongollo, "Aeration in Growing Media: Recent Developments,” Acta Horticulturae, Vol. 481, 1999, pp. 545-551.

[43] A. H. Vuorienin and M. H. Saharinen, "Evaluation of Microbial and Chemical Parameters during Manure and 
Straw Composting in a Drum Composting System,” Agriculture, Ecosystems and Environment, Vol. 66, No. 1, 1997, pp. 19-29. doi:10.1016/S0167-8809(97)00069-8

[44] A. Bary, C. Cogger and D. Sullivan, "What Does Compost Analysis Tell You about Your Compost?” Poster at Biologically Intensive and Organic Farming Research Conference, Yakima, 2002.

[45] W. F. Brinton, "Compost Quality Standards and Guidelines,” Wood and Research Laboratory, West Lafayette, 2000, pp.1-41.

[46] Canadian Food Inspection Agency, "Standards for Metals in Fertilizers and Supplement," Trade Memorandum, T-4-93, 1997.

[47] G. R. E. M. Van Roosmallen, J. W. A. Lustenhouwer, J. Oosthoek and M. M. G. Senden, "Heavy Metal Sources and Contamination Mechanisms in Compost Production," Resources and Conservation, Vol. 14, 1987, pp. 321-334. doi:10.1016/0166-3097(87)90032-0

[48] E. S. Dias, S. E. Guimaraes, F. G. de Siqueira, R. da Silva and L. R Batista, "Allergenic and Toxigenic Fungi in the Compost of Cultivation of Agaricus brasiliensis," Scientia Agrarian, Vol. 10, No. 6, 2009, pp. 507-511.

[49] P. D. Millner, P. B. Marsh, R. B. Snowden and J. F. Parr, "Occurrence of Aspergillus fumigatus during Composting Sewage Sludge,” Applied and Environmental Microbiology, Vol. 34, No. 6, 1977, pp. 765-772.

[50] Anonymous, "Method for Testing Municipal Solid Waste Compost," Standardization Organization for G. C. C. (GSO) 1167, 2002. 